\title{
THE EFFECTIVENESS OF REFORMS IN PUBLIC SECTOR ACCOUNTING AND FINANCIAL MANAGEMENT: THE CASE OF SPAIN, 2010-2015
}

\author{
Yulia Kasperskaya \\ Ramon Xifré
}


The Public-Private Sector Research Center is a Research Center based at IESE Business School. Its mission is to develop research that analyzes the relationships between the private and public sectors primarily in the following areas: regulation and competition, innovation, regional economy and industrial politics and health economics.

Research results are disseminated through publications, conferences and colloquia. These activities are aimed to foster cooperation between the private sector and public administrations, as well as the exchange of ideas and initiatives.

The sponsors of the Public-Private Sector Research Center are the following:

- Ajuntament de Barcelona

- Departament d' Economia i Coneixement de la Generalitat de Catalunya

- Departament d' Empresa i Ocupació de la Generalitat de Catalunya

- Diputació de Barcelona

- EVERIS

- Fundació AGBAR

- Institut Català de les Empreses Culturals (ICEC)

- PricewaterhouseCoopers

- Sanofi

The contents of this publication reflect the conclusions and findings of the individual authors and not the opinions of the Center's sponsors. 


\title{
The effectiveness of reforms in public sector accounting and financial management: the case of Spain, 2010-2015
}

\author{
Yulia Kasperskaya $^{1}$ \\ Ramon Xifré ${ }^{2}$
}

November 2016

\begin{abstract}
This paper interprets through theoretical lenses the public sector financial management reforms adopted in Spain between 2010 and 2015. In this period, coping with intense external pressure, the country passed many fiscally-oriented reforms to escape the 2008 crisis including a change in the constitution. We study the changes that have been adopted in three key public accounting and financial management areas: budgeting, reporting and auditing. Our main research question is whether this series of reforms are likely to have had both a disruptive and positive impact in the Spanish public sector management model. We approach the question in the light of three theoretical contexts: the resource dependence model, the logic of discipline and the leadership-task perspective. Our analysis does not support a strong affirmative answer to the question. The fiscal crisis has been averted but it appears that it is more because of discretionary consolidation efforts rather than the result of adopting structural policies. Our work also highlights some dimensions in which Spain is lagging behind leading practices in the EU. Value for money auditing and accountability standards are still low and the independence of certain critical bodies is not sufficiently protected.
\end{abstract}

Keywords: financial management, structural reforms, public accounting, Spain JEL codes: H11, H61, H63

\footnotetext{
${ }^{1}$ Universitat de Barcelona, Departament d'Economia i Organització d'Empreses. yulia.kasperskaya@ub.edu

${ }^{2}$ ESCI - Universitat Pompeu Fabra and Public-Private Sector Research Center, IESE Business School. ramon.xifre@esci.upf.edu
} 


\section{Introduction}

Both the global financial crisis of 2008 and domestic idiosyncratic weaknesses caused Spain to suffer one of the strongest fiscal crises of advanced economies in recent times. Between 2007 and 2015, general government public debt as a percentage of GDP practically tripled, crossing the $100 \%$ mark. Spain suffered international market panic episodes in 2010 and 2012 as the perceived risks of sovereign default escaped from the negligible magnitude region. As a result, Spanish public sector financial management has come under criticism (Caamaño Alegre and Fernández Leiceaga, 2016; and Albi and Onrubia 2016). Indeed, within the EU, the vulnerability of the public finances and the shortcomings of public sector management are not an exclusive feature of Spain but also extend to other southern countries like Greece, Italy and Portugal (Di Mascio and Natalini, 2013; and Bailey et al. 2014).

These experiences have taken place against a relatively underdeveloped economic governance framework in the EU. Indeed, the process of setting the economic governance rules in the EU, including its fiscal dimension, appears to be driven more by the needs of the day rather than following a pre-established and agreed-upon plan or blueprint. In particular, the Stability and Growth Pact, which has already shown to have had a limited effect before the crisis (Fingland and Bailey, 2008), has turned out to be practically useless in order to contain the fiscal consequences of the crisis in the EU (Bénassy-Quéré et al. 2016).

The severity of the problems in Spain, and the fear that potential economic accidents in the country could destabilize the whole EU, has resulted in some economic reformism adopted in Spain (Xifré, 2014). A central goal of these economic policy reforms has been the improvement of fiscal governance and public sector financial management in general. Numerous legislative reforms with implications for public financial management have been passed between 2010 and 2015 in Spain, including a change in the country's constitution.

Our main research question is whether this series of reforms are likely to have had a disruptive and positive impact in the Spanish public sector management model. For this reason, we systematically examine public sector financial management reforms adopted since 2010 in three key areas; budgeting, reporting and auditing. Although these three 
areas are not completely isolated from each other, it is convenient to review the legislative and institutional developments separately.

To gain some perspective, we approach the research question in the light of three theoretical contexts: the resource dependence model, the logic of discipline and the leadership-task perspective. These theoretical constructs have proven to be particularly fruitful in the recent literature when examining public sector reforms and crisis management in other fiscally-stressed EU countries.

We believe it is important to relate Spanish reform initiatives with the corresponding trends in the EU for various reasons. In some cases, the reforms in Spain are directly affected by EU-wide harmonization processes, like the process of adoption of accounting standards (EPSAS). In some others, like those regulations more related with budgeting and fiscal rules, the ongoing debates on the creation of a fiscal union in the Euro area provide a useful benchmark in terms of the principles that a sound public financial reform should follow (Claeys et al. 2016). Finally, more generally and with a historical perspective, it is clear the influence that the EU has had in shaping Spain's fundamental building blocks in public sector management, like governmental accounting (Montesinos and Vela, 2000).

The paper is focused on central government budgeting and financial management in Spain. Regional governments are considered in the analysis in so far their budget and financial resources are largely determined by the central government in the cases of fifteen out of the seventeen regions in Spain (all of them, except the Basque Country and Navarra which enjoy fiscal quasi-independence).

The rest of the article is organized as follows. Section 2 outlines the methodology and data sources. Section 3 presents the three theories we will be considering. Section 4 identifies the reforms that have been adopted in Spain. Finally, section 5 concludes by analysing to which extent the logic behind the actual reforms is aligned with the theory's predictions.

\section{Methodology and data sources}

The analysis of our research question requires three methodological stages. 
In the first one, we critically review three theoretical setups that are applicable to the study of public sector reform policies: the resource dependence model, the logic of discipline and the leadership-task perspective. These models will then be the lenses through which we will interpret the actual changes that have been adopted in Spain between 2010 and 2015 in public sector accounting and financial management. The reason for considering these three theoretical constructs is that they have been demonstrated to be particularly fruitful when analysing public administration reforms and crisis management in some fiscally-stressed EU countries like Italy or Greece.

The second stage requires the analysis of the reforms actually adopted in Spain and it involves two sources of information. On the one hand, there is the archival information contained in the Spain's National Reform Programme (NRP). These are public, official documents issued by all EU member states that "present the country's policies and measures to sustain growth and jobs and to reach the Europe 2020 targets" (European Commission, 2016). The NRP is presented jointly with the Stability and Convergence and National Reform Programmes. They are a core element of EU economic governance and they set out countries' budgetary scenarios and plans for the medium run (usually three to four years). We survey all the available Spanish NRPs, which correspond to the years 2011 - 2015. On the other hand, it is necessary to check the actual regulations that have been passed by the Parliament and for this reason, we check the commitments contained in the NRP with the laws and royal decrees that have been effectively passed.

Finally, in the third stage we combine both perspectives; the analytical one and the facts-based one. Our aim here is to identify the leading rationales behind the recent reforms in public sector accounting and financial management in Spain. This allows us to address our main research question: to which extent these reforms have been effective in changing the public financial management style in Spain.

\section{Theoretical setups}

\section{The resource dependence model}

The resource dependence model was initially proposed by Pfeffer and Salancik (1978) and it explores how external constraints affect organizations. According to this vision, which shares a number of elements with neo-institutional theory, all organizations are dependent on the environment to obtain resources and survive. In certain extreme cases, 
this theory predicts that one organization could be directed by other entities and not by itself.

In the public sector sphere, there has been a wide application of the resource dependence theory. Mizruchi and Fein (1999) argue that governmental action might be constrained by other governments or supra-national organizations from which they have a financial dependence. As Cohen and Karatzimas (2016) note, public administrations struggling to survive are most likely to enter financial support mechanisms set out by international lenders like the IMF and, in such circumstances, governmental decisionmaking will probably receive pressure from the providers of funds.

More to our point, when analysing public sector accounting and management reforms, Carpenter and Feroz (2001) point out that the resource dependence model helps explain why the choice of certain national accounting practices are undertaken under some "coercive isomorphic pressures" from an external organization that provides funds. This theoretical approach has been employed by Cohen and Karatzimas (2014 and 2016) to study different episodes of the budgeting and public administration reforms in Greece. These authors find that the resource dependence theory contributes to explaining why programme budgeting was first introduced and then suddenly abandoned in Greece (Cohen and Karatzimas, 2014) and how the participation of the Troika (European Commission, European Central Bank and International Monetary Fund) changed priorities in the central government accounting reform (Cohen and Karatzimas, 2016).

\section{The logic of discipline}

The logic of discipline (Roberts 2010a and 2010b) is a conceptualization of a doctrine, prevalent in certain policy circles, that is sceptical about conventional methods of democratic governance. Under this doctrine, democratic governance of public affairs could degenerate in poor decision-making: produce polices that were short-sighted, unstable or tailored to special interests. As a result, it could be optimal from a social point of view to impose restrictions on the democratic process by transferring power from the government to technocrats or independent bodies, who "would make difficult decisions that voters and legislators appeared to be incapable of making otherwise" (Roberts 2010b).

The first field of public governance where this doctrine was applied was in the design of central banks. Partly in response to the inflation episodes of the 1970s, it gradually 
became self-evident in most advanced economies from the 1980s onwards that central banks should be "independent" and operate completely disconnected from party politics (Patel, 2008).

The sound reputation of independence and strong discipline extended from central banking to other realms of public policy. In advanced economies, it was widely considered that regulatory tasks should be transferred from the government to new organizations that were deliberately insulated from political control (Gilardi, 2008). Similarly, the management (building, maintenance and commercial exploitation) of certain large infrastructure projects like ports or highways was generally considered to be better handled if the "independent" private sector was on board by means of longterm infrastructure contracts (Boyco et al. 1996). In developing countries alike, the logic of discipline and independence was applied chiefly to one of their key problems in the 1980s and 1990s, tax and public revenue collection. The model for the implantation of new revenue agencies in many countries was the Autonomous Revenue Authority (ARA). In this model, tax collection functions were extracted from ministries of finance and established as separate bodies (Taliercio, 2004; Kidd and Crandall, 2006).

The logic of discipline and the delegation of power to technocrats also extended to public budgeting institutions and procedures, with strong support from the mainstream economics literature. Nordhaus (1975) pioneered the warnings against "the Sirens of partisan politics" when it came to make budgeting and expenditure decisions and advocated for a "Treasury dominated by civil servants". After two decades of looking at the issue, drawing analogies with central banks, Von Hagen and Harden (1995) and Alesina and Perotti (1996) vindicated the 'top-bottom' budget processes, heavily controlled by strong, "independent" finance ministers relative to Spending Ministries. More recently, Wyplosz (2005) argued that budgetary performance could be improved in general by relying on a committee of "unelected" experts.

According to Roberts (2010b), this way of thinking was already facing criticism before the crisis but in its aftermath the legitimacy of "technocratic governance" has been badly damaged for a number of reasons. In his view, the main assumption behind this doctrine, the idea that technocrats could be trusted to exercise discretion properly, has been revealed to be highly problematic after the crisis. Essentially, some developments after 2008 in several advanced economies have exposed the limitations of the competency and the independence of technocrats. 


\section{The leadership-task perspective}

The leadership-task perspective (Boin et. al 2005) stresses the role of appropriate leadership, individual or in a group, to deal with the crisis and threats of all types (conflicts, man-made accidents, social and political tensions, etc.). From this perspective, policymakers are expected to avert the threat, minimize damages and lead the community out of the crisis. This vision calls for public leaders to undertake five critical and specific tasks: sense-making, decision-making, meaning-making, terminating and learning.

Several insights from this theoretical construct have been applied to study how southern EU countries have managed their public finance crises. Zahariadis (2013) employs this approach to study the crisis-reform dilemma in Greek public finances (2009-2012). The paper reaches the conclusion that there is a trade-off between short-term crisis management and long-term reform, with the former generally dominating the latter. The work argues that some of the key reasons for this were electoral calculations by the incumbent politicians and the perception by the Greek population of the involvement of foreign actors in their crisis.

In the case of Italy, Di Mascio et al. (2013) approach a similar question, the cutbacksreform dilemma faced by the country in the aftermath of the 2008 crisis. This study runs deeper in the historical perspective and relates the country's response to the past episode of the 1992 crisis, when Italy's currency was expelled from the European Monetary System. The work argues that the political leadership and management of the Italian fiscal crisis were heavily influenced by pre-existing policy repertories and, in particular, cutbacks in public expenditure were privileged over managerial reforms in the public sector.

What these two works find, interpreted through the lenses of the leadership-task perspective is that the political leadership in these countries has encountered difficulties to perform the tasks that were necessary to manage the aftermath of the 2008 crisis, particularly sense-making and decision-making. 


\section{The reforms in Spain, 2010 - 2015}

\section{Budgeting}

In most advanced countries, and in particular in the EU, the public management reformist agenda in budgeting pursues, among others, the following main objectives: enhancing budget stability and sustainability; advancing in performance budgeting; and improving the administration of the budget process. From a policy perspective, these prescriptions can be illustrated by recommendations from the European Commission (European Commission 2010 and 2015) and the International Monetary Fund (Andrle et al. 2015 and Eyraud and $\mathrm{Wu}, 2015)$. We review the budgeting reforms in Spain following these three subareas.

\section{a. Budget stability and sustainability}

The objective of budget sustainability was not entirely new for Spain before 2010. A budget stability law had been passed in 2003 (Law 47/2003) that established ceilings for the budget deficits at all levels of the public administration as not exceeding a combined limit of $1 \%$ of GDP. However, this was subsequently amended and its terms relaxed in 2006 by means of a new law (Law 15/2006).

In the wake of the economic crisis of 2008, the Council of the European Union notified Spain in April 2009 of the existence of an excessive deficit (Council Decision 2009/417/EC) and the country was put in the excessive deficit procedure (EDP). In these circumstances, the reduction of the public deficit became a top priority for public management in Spain since May 2010 when, being under strong "external pressure" (Kickert and Ysa, 2014) from the EU, the Spanish government started a fiscal austerity plan in the central government (by means of Royal Decree Law 8/2010) which was later extended to all levels of sub-central government.

The Spanish general government deficit represented 11\% of the GDP in 2009 and $9.4 \%$ in 2010. On the one hand, it is likely that this pace of convergence to budget stability was deemed to be too slow for a time of severe international market turbulences. On the other hand, the prevailing impression was that Spain could not be fiscally bailed out in the same conditions that Greece, Ireland, Portugal and Cyprus had been from the onset of the crisis, due in large part to the economic size of the country. For these reasons, an extraordinary political move took place in September 2011 when Spain changed article 135 of its constitution. This change could not be undertaken by means of a law but 
required instead a reinforced majority vote by the parliament. The vote was won by 316 votes to 5 votes against. The new article establishes that all public administrations will adhere to the principle of budget stability and that central and regional governments cannot exceed the limit of structural deficit stipulated by the European Union for its member states, with the exception of situations of natural catastrophes, great economic recession and emergencies. The reform of the constitution mandated a further specification of the budget stability and sustainability conditions in an organic law.

This law on budget stability and financial sustainability was approved in April 2012 (Law 2/2012). The new law stipulates that all public entities are obliged to have null deficit or budget surplus. Central and regional governments may have structural deficits only in situations of force majeure and the level of public debt cannot exceed $60 \%$ of GDP. The law contemplates that there is a transitional period for achieving these objectives, which ends in 2020. It also stipulates the mechanisms of alert and punishment in case governments do not fulfil these requirements: public entities first have to produce the explanations on their budget deviations and then adopt measures to restore budget discipline. The law also includes obligations on reporting: public bodies need to establish the equivalence of their budgets with national accounts systems for the reliable estimation of deficit and debt.

Finally, the major reform adopted in the institutional setup to enhance budget stability in Spain was the creation of the Spanish Independent Fiscal Authority (AIReF) in November 2013 (Organic Law 6/2013). The incorporation of such a body was a longstanding demand from the European Commission and other international observers. By legal mandate, the AIReF is in charge of overseeing the compliance of budget stability by all levels of government in Spain and producing the macroeconomic projections and mid-term scenarios that support the budgets. However, by law, the AIReF's role in the Spanish budget process is not binding; it can produce opinions and reports but it has no possibility of conditioning or limiting in any respect the governments' fiscal discretion.

\section{b. Performance budgeting}

The Spanish budget provides three types of classification of expenditure: by objectives (the programmes where the money is to be spent), by the type of expenditure (current operations, capital operations, financial operations and contingency funds), and by the spending entities (central administration, regional entities, state agencies, social security and others). The first classification is the most relevant for assessing expenditure 
performance; programmes are also classified as programmes with measurable objectives (for example, "creation of the road infrastructure") and instrumental programmes without measurable objectives (such as programmes of management and planning within the ministries).

The budgets of the last years contain as many as 200 individual programmes, 87 groups of programmes, 26 policies of expenditure and 5 major areas of expenditure. Overall, according to the OECD (2014), the Spanish budget provides one of the most comprehensive and complex budget taxonomies, amounting in 2012 to 15,479 budgetary items; only budgets in Japan, Turkey and Portugal work with a more detailed categorization. The problem is that despite such a detailed level of budget presentation and programme classification, very scarce efforts have been made to link budgetary execution with policymaking.

The general budgetary law requires (article 31 of Law 47/2003) governmental entities to set up medium-terms programmes with defined objectives. It states that the allocation of resources should be carried out in accordance with the attainment of these objectives in the previous exercises. However, performance budgeting in Spain has degenerated in most of the instances in the ritual of stating the objectives in long and voluminous reports by the Spending Ministries without any binding evaluation a posteriori (we will return to this issue below, when the analyse reporting). For example, in the Report of the 2012 Central Government budget, 909 objectives and about 5616 indicators were stated. These magnitudes do not allow for any systemic analysis of the execution of the programmes' objectives (Caamaño and Fernandez, 2016).

Consistent with this observation, according to the OECD (2014) Spain reported one of the lowest scores on the use of performance information in negotiation with central budget authorities, declaring the poor use of financial data, operational data and performance evaluation and never spending on reviews, statistical data or data of independent analysts. In what is a remarkable lack of accountability, no consequences for poor performance exist in the case of the programmes' poor performance: poor performance is not made public and budgets for poor-performing programmes are not decreased. 


\section{c. Administration of the budget process}

The institutional set-up of the central government's budgeting process has not experienced major domestic legal changes in more than a decade, with the fundamental law that regulates the process dating from 2003 (Law 47/2003) and the major changes resulting from converging with the EU economic governance process.

The convergence with the EU economic governance process implies that, prior to drafting the budget, the economic diagnostic evaluation of Spain should be done jointly by the government and the European Commission. In chronological order, first the Ministry of Economic Affairs and Competitiveness needs to produce, in consultation with the European Commission, the report on the cyclical position of the Spanish economy, which includes a three-year scenario for the main macroeconomic variables. This report, serves as input for the Stability Programme of Spain, which develops a three-year scenario for the public budget, deficit and debt and it is released in April. The Stability Programme together with another high-profile document, the National Reform Programme (which includes structural reform domestic commitments), form the core of the EU economic governance process with which the European Commission monitors member states. The Government then approves the objectives of deficit and debt at all levels of public administration (central government, regional governments, local governmental, and social security) and the Parliament needs to approve the ceiling of non-financial expenditure by the central government by September.

The main entity in charge of elaborating the budget is the Ministry of Treasury and Public Administration, in particular the Directorate of State Budget and Expenditure. Each year, the elaboration of the budget begins with the Ministry of Treasury and Public Administration drawing up the directive which specifies the institutions involved, participating committees and their tasks, the main criteria for spending policies and the timeframes for budget development. The central government's budget needs to be finally approved by the parliament and needs to be presented before October 1 of the previous year.

From a programme or functional perspective, the Ministry of Treasury and Public Administration first organizes the Committee of Spending Policies, which includes the representatives of different departments of other Spending Ministries.

The committee decides the spending priorities according to the objectives of budgetary policy and it suggests allocation criteria given the available budget resources. This 
committee pays special attention to the allocation of the resources of EU funds, such as the Structural Fund and the Cohesion Fund.

After this, the Committees of Programme Analysis are organized with the objective of analysing programmes regarding their objectives and funding necessities. These committees include representatives from all ministries and they are expected to play an important role in the selection of programmes, their follow-up and negotiation with the Ministry of the Treasury (Central Budget Authority) on programme objectives and funding. Yet, in practice, there is no evidence that these committees can alter in any significant way the budgetary allocations imposed by the Directorate of State Budget Expenditure (Ballart and Zapico, 2009). The decision-making on budgetary objectives and programmes remains centred on administrative procedures and compliance with the legal code. There is a lack of genuine negotiation on programme objectives occurring across the ministries and there is no involvement in budgetary decision-making of external experts (Zapico, 2012). Likewise, there is a lack of transparency on budgetary decision- making concerning the disclosure of procedures and methodologies of budget appropriations and evaluation a posteriori of budget programme objectives.

\section{Reporting}

Spain has a dual system of financial reporting in place. In 2010, Spain undertook the major reform of the public accounting system adopting the full accrual accounting method for their general-purpose financial statements (Ministry of Economy and Finance, 2010). According to Brusca et al. (2013), the adoption of accrual reporting in Spain was fostered by two factors. On the one hand, it was the desire of mirroring the reporting practice of private enterprises, which adopted IFRS in 2007. On the other hand, it was imperative to align the Spanish public accounting with the IPSAS, which gained legitimacy among the national standard-setters at that time.

At present, Spain is one of the few countries where financial reporting is actually done on the full accrual basis, including all the levels of government, central, regional and local (Rossi et al., 2016). However, the adoption of full accrual accounting refers only to general-purpose financial statements of governmental entities. Reporting to legislature for the general public remains cash-based and therefore the mechanics of budgetary discussion and approval remain unchanged (Brusca et al., 2013). 
Similar to other European countries, Spain employs the European System of National and Regional Accounts ESA 2010 (Eurostat, 2013) for the elaboration of statistics for Eurostat, in particular, on the public debt and deficit. In this respect, the European Commission (European Commission, 2013) points out that high quality accounting data reported on an accrual basis is essential for the credibility of the budget deficit and debt data of the member states and, hence for enhanced fiscal governance.

The reliability of current deficit estimates across Europe is doubtful due to diverse accounting regimes throughout it (Jesus and Jorge, 2015). The European Commission therefore launched the initiative of harmonizing public accounting across Europe by creating the European Public Accounting Standards (EPSAS), which take as a reference point the accrual-based International Public Accounting Standards (IPSAS).

Spain's stance seems to be good to converge with EPSAS since their current standards are IPSAS-based. However, judging on the authoritative opinion of the Spanish Independent Fiscal Authority, the pending issue is to elaborate the manuals allowing it to establish the correspondence between the budgetary reporting and the system of national accounts in order to produce homogeneous estimates of deficit applicable at all levels of the public administration (AIReF, 2014).

\section{Auditing}

In Spain, there are two main public bodies with the responsibility of overseeing and controlling public financial management practices and there have been no major changes in the institutional architecture in recent times.

The Internal Audit Office (IGAE, Intervención General de la Administración del Estado/The General Intervention Board of the State Administration) is part of the executive branch of the Ministry of Treasury and Public Administration. The mandate of IGAE is (1) to ensure the veracity and compliance of financial statements with the legal norms and (2) to control the efficiency and effectiveness of public spending and fulfilment of budgetary objectives. The first part of IGAE's mission corresponds to traditional compliance auditing. The second objective implies that IGAE should undertake the evaluation of spending outcomes, in correspondence with the modern vision of auditing as a performance-oriented or value for money audit. 
The second body, considered to be the supreme public audit institution in Spain, is the Court of Auditors (Tribunal de Cuentas). The mission of this institution is to ensure the legality of financial management practices at all levels of public administration and, in the case of detecting misconduct, to initiate prosecution. In principle, the Court of Auditors is accountable to the parliament and it is independent from the executive. Eleven out of the seventeen regional governments in Spain have also created the analogous external control bodies, which also extend their attributes to controlling local governments.

The benchmark practices in auditing imply that auditing agencies shall act independently from the executive, hire highly qualified professionals with diverse expertise and use this expertise to assess the efficiency or effectiveness in the use of public funds. On occasions, auditors can even advise on how funds can be used in the most effective way before spending them and promote the best practices of internal management within governmental entities. Hence, the focus of modern audit shifted from compliance objective to value for money objective (INTOSAI, 2010)

In Spain, both the IGAE and the Court of Auditors (Tribunal de Cuentas) are legally entitled to run audits aimed at determining the effective and efficient usage of public funds. Yet, in practice, the scope of their activities is limited to compliance and verification audit only (OECD 2015; Albi and Onrubia, 2016). In addition, there are serious concerns about the independence of these bodies. The IGAE staff is formed from civil servants with permanent tenure in ministries and the ruling political party heavily influences the hiring process in the Court of Auditors (Tribunal de Cuentas).

Perhaps being aware of the lack of impact assessment carried out by existing public auditing bodies, the Spanish government in 2007 created the State Agency for Public Policy Evaluation and Quality in Services (Agencia de Evaluación y Calidad). This agency is entitled to evaluate the impact of government policies and programmes and to assess the quality of the provision of services in order to enhance accountability. Being thought originally as an independent agency, in 2012 it became a unit of the Ministry of Treasury and Public administration. Judging on the publicly available reports, its activities regarding the evaluation of government policies are very limited in scope and extension. For example, in 2015 (no information is available for 2016), the Council of Ministers commissioned this agency the impact assessment of two reforms; the Law on 
the Single Market and a set of measures to reduce the cost of public late payments in the private sector (Council of Ministers, 2015).

\section{Discussion and conclusions}

The previous sections have analysed the major reforms in public auditing, budgeting and reporting adopted in Spain since 2010 and three theoretical explanations that have been applied to rationalize this type of interventions in other EU-periphery countries. The goal of this part is to interpret these reforms through the analytical lenses in order to answer our main research question, that is, the extent to which this wave of reforms might have effectively changed the Spanish public sector management model.

In the case of auditing, there has not been much reform action since 2010. The latest major change in the institutional architecture of the auditing process was in 2007 and there have been no significant legal changes that expand the attributions, roles or scope of existing auditing bodies. The absence of reforms in this area, however, is not due to the fact that Spain excels in public sector auditing according to international standards. While compliance at central government level seems to be reasonably taken care of, compliance at subcentral levels of government (regional and large municipalities) cannot be taken for granted.

But more than anything else, there is no systematic system for evaluating public policies carried out by an independent body with public sector support, which is considered to be one of the best arrangements for conducting external auditing and increasing value for (public) money in most advanced countries. The executive selects a few programmes or policies to be reviewed each year by an agency that forms part of the government itself. In this relatively closed, non-transparent system, it is not known what happens when a public policy or public agency receives low scores from the evaluation agency and the fears of lack of independence of the evaluators are reinforced.

This can be rationalized from the leadership-task perspective (Boin et al. 2005) as an instance in which the implementation of fundamental reforms is postponed because the public leadership devotes most of its energies to decision-making rather than sensemaking. As Zahariadis (2013) argues for the Greek case, there is also a trade-off between crisis management and reform in Spain. Our analysis suggests that concerning 
auditing, the former has been dominant over the latter resulting in practically no major reforms being implemented in this key element of public management.

This lack of a public policy evaluation culture in Spain is aggravated by the fact that the budgeting process itself is not particularly performance-friendly in practice. The very large number of budgetary items and expenditure programmes in the Spanish budget taxonomy appears to create the "illusion" (Wright, 1999) of expenditure control while making it difficult to monitor in a simple and transparent way the performance of the public sector. The transition from a large set of indicators hinders the tracking of a small set of spending priorities that are clearly linked with policy outcomes and easy to monitor, similar to strategic expenditure reviews practiced in some developed countries (Shick, 2013) has not occurred in Spain yet while it is highly desirable.

The failure to adopt a more comprehensive culture of public policy evaluation in Spain could be better understood through the lenses of the logic of discipline (Roberts 2010a and 2010b). Weak evaluation systems lead to poor levels of accountability of public activity, erode the representation of the political system and ultimately are detrimental to the welfare of citizens. This state of affairs can be rationalized if the budget process and policy evaluation are largely in the hands of a selected group of professional civil servants, who are protected from political intervention - but also isolated from the general public concerns to increase the efficiency of public spending. Without being categorical in this point, it is possible that the precarious state of policy evaluation in Spain is the result of a tradition and a well-intentioned rationale to professionalize the civil service and entrust the control of the budget process to technocrats. In this setup, only the process insiders (permanent civil servants) have the key to unlock any successful budget reform. Ultimately all this might reflect that there are still certain deficits in the quality of the democratic governance of the country, as Field and Hamann (2008) have convincingly argued for a number of issues.

Concerning the administration and procedures of the budgeting process, in most instances it is still done in a heavily bureaucratic way, involving multiple ministerial committees but lacking true budget negotiation, interaction and communication between ministries and transparency regarding budget allocations. There is no involvement of external experts in budgetary decision-making, in contrast to Sweden and Netherlands where external specialists play an active role in budgetary decision-making (Zapico, 2012). This Spanish tradition can also be partly explained in terms of the logic of 
discipline, with the main rationale being to protect the budget process from unduly political/partisan interference and pressures.

In this respect, the case of the creation of the Spanish Independent Fiscal Authority (AIRef) is very interesting because its conception reflects the combined effect of two rationales; the logic of discipline and the resource dependence model. The creation of an independent and technocratic fiscal council was strongly and repeatedly requested by the European Commission (Council of the European Union, 2013).

In terms of reporting, the preparation effort done has set the country relatively well positioned, in terms of EU standards, to adopt EPSAS. Perhaps because this is an issue more technically than politically loaded, progress here has been remarkable. There is, however, a non-negligible pending task in this respect which is to produce homogeneous estimates of deficit applicable at all levels of the public administration.

Finally, concerning budgeting and fiscal policy, the assessment appears to be rather mixed. On the one hand, Spain has averted the threat of a fiscal crisis that had been assigned a non-negligible probability by the market, which reached panic episodes in 2010 in 2012 in bond markets (Financial Times, 2012). However, this appears to be the result much more of certain political decisions of cutting expenditure rather than the manifestation of true structural reforms that one can confidently predict to last (LagoPeñas, 2016).

The Spanish constitution was amended in 2011 to include a strict budget sustainability goal but, in practice, the country is still in transition to this new scenario that should be reached by 2020 . In addition to this, the change in the constitution refers to the determination of the actual fiscal rule to a law that could be changed at any moment before the end of the transition period. And, more importantly, the very delicate issue of the rule for financing regional governments in Spain was left without reforming. In so far as this is one of the major sources of political and fiscal tension in the country, no global fiscal framework can be considered stable unless it includes a reasonable and sustainable proposal, which, unfortunately, it is still not the case.

These last two points, the public spending cuts and the amendment of the constitution, implied a very significant political cost for the incumbent government at the time. As such, they can only be understood as the reaction of Spanish politicians to intense 
"external pressure", as Kickert and Ysa (2014) have argued, to adopt first reforms in exchange for the subsequent financial support needed to recapitalize the financial system (Carbó Valverde and Rodríguez Fernández, 2014). Therefore, they are clear instances of the resource dependence model (Pfeffer and Salancik, 1978; Cohen and Karatzimas, 2014) where the decisions of a government are conditioned by external parties.

To sum up, de jure Spain undertook significant management financial reforms in the last decade, introducing accrual financial reporting, strong fiscal rules and ceilings on budget deficits. However, de facto, it is not clear how they affect the decision-making of governmental officials and efficiency of governmental spending since administrative procedures, evaluation styles and accountability devices remain largely unchanged. The more drastic changes appear to have been driven by the pressure of external actors, in line with the resource dependence model. The doctrine of the logic of discipline and delegation of powers to experts (professional public servants) has been useful to build independent institutions but it might be as well the reason why critical reforms in public budgeting advance so slowly. Finally, the leadership-task perspective offers insights that account for another distinctive feature of the Spanish reform process which has in general privileged immediate crisis management over undertaking deep structural reform. 


\section{References}

Albi, E and Onrubia, J. (2016) Institucionalizar la evaluación económica de políticas públicas: eficiencia y rentabilidad social. Papeles de Economía Española, 147, pp. 50 67

AIRef (2014) Opinion: Cambios en procedimientos del ciclo presupuestario,

Andrle, M., J. Bluedorn, L. Eyraud, T. Kinda, P. K. Brooks, G. Schwarts, and A. Weber (2015). Reforming Fiscal Governance in the European Union. IMF Staff Discussion Note SDN/15/09.

Bailey, S. J., P. Valkama, S. Salonen (2014). The EU's public finance crisis: causes, consequences and cure. Public Money \& Management, Vol. 34, Iss. 2, 93-90.

Ballart, X. and Zapico, E. (2009) Budget reforms in Spain - beyond budget stability to substantive performance in The Reality of Budget Reforms: Counting the Consequences in 11 Advanced Democracies. London.

Bénassy-Quéré, A., X. Ragot, and G. B. Wolff (2016). Which Fiscal Union for the Euro Area?. Bruegel Policy Brief, 2016/06.

Boin, A., P. 't Hart and B. Sundelius. The Politics of Crisis Management: Public Leadership Under Pressure. Cambridge University Press.

Boyko, M., A. Shleifer and R. Vishny (1996). A Theory of Privatisation. Economic Journal, 106 (34), 309 - 316.

Brusca I., Montesinos, V. and Danny S.L. Chow (2013), Legitimating International Public Sector Accounting Standards (IPSAS): the case of Spain. Public Money and Management, 33, 6, pp. 437-444.

Caamaño Alegre, J. and X. Fernandez Leiceaga (2016) El Ajuste del Gasto en España: Estabilidad, Elaboración de los Presupuestos y Control Financiero. Papeles de Economía Española, 147, 26-49.

Carbó Valverde, S. and F. Rodríguez Fernández (2014). The Spanish banking system: Recent developments and prospects for 2014. Spanish Economic and Financial Outlook, Vol. 2, No.6, 17-26.

Carpenter, V. L. and E. H. Feroz (2001). Institutional Theory and accounting rule choice: an analysis of four US states governments' decisions to adopt generally accepted accounting principles", Accounting, Organizations and Society, Vol. 26, No. 7, 565-596.

Claeys, G., Z. Darvas and Á. Leandro (2016). A proporal to revive the European Fiscal Union. Bruegel Policy Brief, 2016/07.

Cohen, S. and S. Karatzimas (2014). Reporting performance information in the public sector: the moral behind the (non)application of program budgeting in Greece. International Review of Administrative Sciences, vol. 80(3), 619-636. 
Cohen, S. and S. Karatzimas (2016). Choosing 'basics first' over best practices? An overview of the Troika's role on the Greek central government accounting reforms. SSRN Working Paper. Available at SSRN: http://ssrn.com/abstract=2790933.

Council of the European Union (2013). Council Recommendation of 9 July 2013 on the National Reform Programme 2013 of Spain and delivering a Council opinion on the Stability Programme of Spain, 2012-2106. Official Journal of the European Union C 217/81-85.

Council of Ministers (2015). Acuerdo del Consejo de Ministros de 23 de enero de 2015, Num. 75, Sec. 1, p. 26636.

Di Mascio, F. and A. Natalini (2013). Fiscal Retrenchment in Southern Europe. Public Management Review, Vol. 17, No. 1, 129 - 148.

Di Mascio, A. Natalini, F. Stolfi (2013). The Ghost of Crises Past: Analyzing Reform Sequences fo Understand Italy's response to the Global Crisis. Public Administration, 91(1), 17-31.

European Commission (2010). Public finaces in the EMU. Directorate-General for Economic and Financial Affairs.

European Commission (2013), Report from the Comission to the Council and the European Parliament. Towards implementing Harmonised Public Sector Acounting Standards in Member States. The suitability of IPSAS for the Member States, accessed at http://eur-lex.europa.eu/legal-content/EN/

European Commission (2015). Public finaces in the EMU. Directorate-General for Economic and Financial Affairs.

European Commission (2016). The European Semester (On-line content; last access September 29, 2016). http://ec.europa.eu/europe2020/making-it-happen/index_en.htm

Eurostat (2013), European System of National and Regional Accounts: ESA 2010

Fingland, F. and S. J. Bailey (2008). The EU's Stability and Growth Pact: Its Credibility and Sustainability . Public Money \& Management, Vol. 28.4, pp. 223-230.

Eyraud, L. And T. Wu (2015). Palying by the Rules: Reforming Fiscal Governance in Europe. IMF Working Paper WP/15/67.

Field, B. N. and K. Hamann (2008 eds.) Democracy and Institutional Development. Spain in Comparative Theoretical Perspective. Palgrave Macmillan.

Financial Times (2012). Politics is adding Spanish Woes. Madrid shares the blame for latest bond market panic. Last access: September 29, 2016. http://www.ft.com/cms/s/0/00fab0a2-d580-11e1-af40-

00144feabdc0.html\#axzz4LfOtAnBz

Gilardi, F. (2002). Policy Credibility and Delegation to Independent Regulatory Agencies: A Comparative Empirical Analysis. Journal of European Public Policy, 9(6), 873-893. 
INTOSAI (2010) “ISSAI 3100 - Performance Auditing Guidelines: Key principles, approved at XXth Congress of INTOSAI; Johannesburg.

Jesus M.A. and Jorge S.( 2015), Governmental budgetary reporting systems in the European Union: is the accounting basis relevant for the deficit reliability? International Review of Administrative Sciences , 81, 1, pp.110-133.

Kickert. W. and T. Ysa (2014) "New development: How the Spanish government responded to the global economic, banking and fiscal crisis", Public Money \& Management, Vol. 34 - 6, 453-457.

Kidd, M. and W. Crandall (2006). Revenue Authorities: Issues and Problems in evaluating Their Success. Washington DC: International Monetary Fund.

Lago-Peñas, S. (2016). Fiscal consolidation in Spain: State of Play and Outlook. Spanish Economic and Financial Outlook, Vol. 5, No. 1, 41-48.

Ministerio de Economía y Hacienda (2010), Orden 1037/2010, de 13 de Abril por la que se aprueba el Plan Genral de Contabilidad Pública, BOE N 102 del 28 de abril

Ministerio de Hacienda y Administraciones Publicas (2016), Introduccion a la lectura de los Presupuestos Generals de Estado.

Mizruchi, M. S. and L. C. Fein (1999). The social construction of organizational knowledge: A study of the issues of coercive, mimetic and normative isomorphism. Administrative Science Quarterly, Vol. 44, No. 4, 653-683.

Montesinos, V. and J. M. Vela (2000). Governmental accounting in Spain and the European Monetary Union: A critical perspective. Financial Accountability and Management, 16(2), pp. $129-150$.

Nordhaus, W. D. (1975). The Political Business Cycle. Review of Economic Studies, 42(2), 169-190.

OECD (2014) Budgeting Practices and Procedures in OECD countries, OECD publishing

OECD (2015), Performance-related budgeting and supreme audit institutions" in Government at Glance 2015, OECD Publishing.

Roberts, A. (2010a). The Logic of Discipline: Global Capitalism and the Architecture of Government. Oxford University Press.

Patel, S. (2008). An Independent Bank of England: The Political Process in Historical Perspective. Public Policy and Administration, 23(1), 27-41,

Pfeffer, J. and G. R. Salancik (1978). The External Control of Organization: A Resource-Dependence Perspective. Stanford University Press.

Roberts, A. (2010a). The Logic of Discipline: Global Capitalism and the Architecture of Government. Oxford University Press.

Roberts, A. (2010b). The Rise and Fall of Discipline: Economic Globalization, Administrative Reform and the Financial Crisis. Public Administration Review, Vol. 70, Iss. s1, s56-s63. 
Rossi, M. F., Cohen, S., Caperchione, E. and Brusca, I. (2016) Harmonizing public sector accounting in Europe: thinking out of the box, Public Money\&Management, 36,3, pp. 189-196

Taliercio, R. R. Jr. (2004). The Design, Performance and Sustainability of SemiAutonomous Revenue Authorities in Africa and Latin America. In Unbounded Government: A Critical Analysis of the Global Trend to Agencies, Quangos and Constractualism, edited by Christopher Pollit and Collin Talbot, 264 - 282. London: Routledge.

Xifré, R. (2014). Four years of economic policy reforms in Spain: An analysis of results from an EU perspective. Spanish Economic and Financial Outlook, vol. 3, no. 5.

Von Hagen, J. and I. Handen (1995). Budget process and Commitment to Fiscal Discipline. European Economic Review, 39 (3-4), 771-779.

Wright, M. (1999). Coping with Fiscal Stress: Illusion and Reality in Central Government Budgeting in Japan. In Fiscal Institutions and Fiscal Performance, J. M. Poterba and J. von Hagen (editors).

Wyplosz, C. (2005). Fiscal Policy: Institutions versus Rules. National Institute Economic Review, 191(1), 64-79.

Zahariadis, N. (2013). Leading Reform Amidst Transboundary Crisis: Lessons from Greece. Public Administration, 91(3), 648-662.

Zapico, E. (2012) El presupuesto por resultados ante la crisis fiscal: contabilizando austeridad y crecimiento, Presupuesto y Gasto Público, 69 53-73. 